\title{
Estimating the Impact of Poverty Alleviation Microcredit on the Income of Poor Households Using the Propensity Score Matching Method: Evidence from China
}

\author{
Jie Yu ${ }^{1}$, Xiao Han ${ }^{2}$, Baozhen Chen ${ }^{1}$ and Jinzheng Ren ${ }^{1, *}$ \\ 1 College of Economics and Management, China Agricultural University, Beijing 100083, China; \\ yujie6611@163.com (J.Y.); chenbz@cau.edu.cn (B.C.) \\ 2 Agricultural Trade Promotion Center, Ministry of Agriculture and Rural Affairs of China, \\ Beijing 100025, China; johnjoy@126.com \\ * Correspondence: rjzheng@cau.edu.cn; Tel.: +86-135-2121-0822
}

Received: 24 May 2020; Accepted: 9 July 2020; Published: 14 July 2020

\begin{abstract}
The poverty alleviation microcredit policy is an important financial poverty alleviation policy that has been widely implemented in China in recent years. However, whether this policy can effectively increase the income of poor households is controversial. In order to measure the implementation effect of the policy, we analyzed the mechanism of the poverty alleviation microcredit on the income of poor households. Then, the paper used micro-survey data to conduct an empirical test using the propensity score matching method to study its effect on the production income of these poor households. The results show that the poverty alleviation microcredit positively affects the production income of poor households, including those who are poor due to lack of funds and poor households with female heads. Therefore, we should continue to implement the poverty alleviation microcredit policy, and establish relevant supporting measures, such as strengthening agricultural production capital subsidies, increasing agricultural production insurance, further improving the implementation efficiency of the poverty alleviation microcredit policy, and increasing the income of poor households.
\end{abstract}

Keywords: poverty alleviation microcredit; production and operation income; policy effect

\section{Introduction}

China has become the country with the largest reduction in the number of poverty-stricken people in the world and the first developing country to achieve the poverty reduction goals of the United Nations Millennium Development Goals, with a contribution rate of over $70 \%$ to global poverty reduction. The poverty alleviation microcredit policy is one of the most important financial poverty alleviation policies implemented to help poor households overcome difficulties when applying for loans. Since the implementation of the targeted poverty alleviation strategy in 2013, the poverty alleviation microcredit began to appear. The poverty alleviation microcredit policy is a kind of credit based on microcredit and combined with the goal of poverty alleviation, which supports the industrial development in poor areas and employment and entrepreneurship of the poor, such as planting, breeding, and other production projects. In 2017, the implementation of the poverty alleviation microcredit policy was further standardized. It is stipulated that the poverty alleviation microcredit can only be used for the poor households who use it to expand production. Additionally, the loan cannot be used for nonproductive expenditure of poor households such as building houses, financing, purchasing household supplies, etc., as well as for government or enterprise. Theoretically, the poverty 
alleviation microcredit is the same as the microcredit, which is mainly focused on the market and supplemented by the policy. Through the cooperation of the government, market, and society, it provides microcredit for the poor households who have the will and ability to get rid of poverty, but also face the shortage of funds. The poverty alleviation microcredit provides the poor households with loans of less than 50,000 yuan and less than 3 years. The loan, without the need for guarantors or collateral for poor households, is issued on the basis of the benchmark interest rate with financial subsidies all interest and county-level risk compensation payments. At the same time, it is supported by various financial services such as insurance, guarantee, and so on. In July 2019, the Notice on Further Promoting Sound Development of Poverty Alleviation Microcredit was issued, serving as both guidance and support for the poverty alleviation microcredit from the policy perspective at the current stage and in the near future. According to the statistical data released by the State Council Leading Group Office of Poverty Alleviation and Development, by the end of April 2019, the nation's poverty alleviation microcredit loans totaled 562.2 billion yuan, of which 307.4 billion yuan was repaid. The loan-to-credit ratio (that is, the proportion of the number of poor households who have obtained credit to the number of all the poor households who have been accurately identified and registered in the poverty alleviation database.) for poor households increased from $2 \%$ in 2014 to $46 \%$ at the end of 2018, benefiting 14.2 million poor families [1].

The application process for the poverty alleviation microcredit is as follows: financial institution and financial service departments of village, township, and county examine and approve credit rating and granting to the poor households who have applied. Then, the poor households apply for loans. Financial institutions independently determine the loan objects and amount, according to the credit rating of the poor households, the scale of production projects, production cycle, and other standards. Finally, financial institutions sign loan contracts with poor households, including the loan amount, loan term, repayment regulations, etc., and grant loans to poor households. At the same time, government departments and insurance companies jointly provide diversified insurance services and insurance products for poor households, set up risk compensation for financial institutions, and reduce credit risk. Government departments provide technical training, market information, and product sales services for poor households to improve their self-development ability and credit utilization efficiency. It is necessary for government departments to understand how poor households use the poverty alleviation microcredit to prevent them from not being used in agricultural production. The poverty alleviation microcredit needs a single repayment of principal on the maturity date and interest-paying monthly or seasonal. There are two ways of financial subsidy interest. First, the poor households pay interest for the credits when it is due. The interest will be fully subsidy by finance after review by government departments. Second, according to the loan amount and interest rate, the finance will subsidize the interest to financial institutions on a quarterly basis, which offsets the loan interest payable by the poor households. Poverty alleviation microcredit, an innovative policy for financial poverty alleviation, uses financial resources to promote industrial development, to drive economic development in poor areas, and to contribute to poverty alleviation. Microcredit for poverty alleviation provides start-up funds for poor households to develop agricultural production and to improve both their endogenous motivation and self-development capabilities. Thus, the effects of the poverty alleviation microcredit policy in China must be analyzed. For instance, how exactly did the poverty alleviation microcredit help the poor? This paper presents an answer to this question and provides future promotion of sound microcredit policy with theoretical support.

There are few studies on the effect of poverty alleviation microcredit. But many scholars noticed the role that microcredit plays in poverty reduction. Poor households lack financial capital [2], and due to the phenomenon of "elite capture" in the rural loan market, the proportion of poor farmers receiving loans from financial institutions (excluding poverty alleviation loans) has decreased year-by-year [3]. Microcredit can effectively solve the problem of insufficient credit for disadvantaged groups [4], ease the credit constraints of the poor and improve their quality of life [5], and increase the availability of financial services and the ability of the poor population to counter poverty, provide financing 
opportunities to expand business [6], and increase their income [7-10]. Even the poorest are able to benefit from the microcredit policy [11]. The poverty alleviation microcredit can improve the ability to manage risks and alleviate the information asymmetry of banks, and greatly reduces the access threshold of formal credit for farmers [12]. However, in contrast, some studies have suggested that microcredit does not considerably increase the income of the poor [13]. For instance, agricultural loans were reported to reduce the total income of low-income farmers due to the large living consumption expenditure of them [14]. Poor households cannot make effective use of microcredit because of lack of effective credit demand $[15,16]$. In addition, poor households can hardly reach the minimum capital scale required by the investment threshold even if they obtain loans, because they receive serious formal financial constraints [17]. All these points of view prove that the various study conclusions are controversial and further research on the impact of microcredit for poor households is needed.

Various studies analyzed the poverty alleviation microcredit from different perspectives, such as the risks and prevention, operational issues, use efficiency, and economic and social benefits, most of which are in the form of empirical analyses, model research, and survey reports. However, studies are lacking about the impact of the poverty alleviation microcredit on the income of poor households, and researchers on the poverty reduction effect of the microcredit have not reached a consensus. Based on micro-survey data, we empirically analyzed the impact of the poverty alleviation microcredit on the production income of poor households. Combined with the estimated results and the relevant literature, we discuss possible reasons for the poverty alleviation microcredit policies affecting poor household income.

\section{Theoretical Model}

The "vicious circle of poverty" points out that the vicious circle of poverty has been trapped for a long time, mainly due to the lack of capital and the serious shortage of capital formation [18]. If there are credit constraints in the economy, reducing wealth inequality can actually stimulate economic growth $[19,20]$. As the core element in the process of modern economic growth, financial development changes the relationship between inequality and growth [21], which is one of the effective ways to alleviate poverty [22]. In the credit market, the ownership and use right of capital can be separated. When the marginal product of capital is decreasing, the rural economy and farmers' income can be improved by sharing capital equally among more farmers. However, credit constraints hinder the sharing of capital equally, which is harmful to the growth of the rural economy and farmers' income [15]. From the perspective of capital supply in the financial market, the interest rate in the financial market is relatively high; therefore, the poor cannot obtain financing. With the wealth accumulation of the rich, the capital supply in the financial market increases, the interest rate decreases, and the income gap gradually narrows under the "trickle-down effect" [23]. From the perspective of the demand side of funds, farmers' formal loan funds are mainly used for production and operation [24]. Based on the theory of productivity factors, farmers obtain loans to finance their production and operation activities as inputs to production, and the welfare of the poor as outputs in some studies; the increase of production and operation investment will significantly increase farmers' income [25]. Farmers then use the income growth from these loans for reproduction, expand the operation scale, improve operation efficiency, and thus continue to increase their income [26,27]. However, the poor are worse off than the rich concerning access to information, education, and entrepreneurship, so the marginal rate of return of the poor is relatively low [28]. The influence channels of microcredit on the poor are as follows: First, the income (or consumption) effect. According to life cycle theory, households should allocate resources effectively in consumption and saving behaviors. Effective external financing is conducive to the realization of cross period allocation of assets, thus affecting consumption smoothing and maximizing household utility $[29,30]$. Second is the substitution effect. More investment time and higher time cost offset the positive effect of income growth. For example, microcredit targets are mostly women, with the increase of women's non-agricultural employment, the opportunity cost of raising children increases [31]. The poverty alleviation microcredit is a financial poverty alleviation policy that 
is different from rural financial marketization. The government provides free financial support for poor households, and these households do not need to bear the opportunity cost of credit. As such, the poor households, the financial institutions, and the government all constitute benefit-related bodies.

The above research provides a good analysis idea for this paper: Through increasing investment in agricultural production and operation, the poverty alleviation microcredit has an impact on the income of poor households and the utility of poor households, but the effect may be weak. In addition, the poverty alleviation microcredit has a different effect on different poor households, such as men and women. Based on this idea, combined with the analysis framework presented by Jia [10], we considered how the poverty alleviation microcredit policy affects the optimal behavior decision making of poor households and how this then affects their income process, and theoretically discussed the mechanism of the poverty alleviation microcredit on the income of poor households. The main body of a rural economy is divided into three categories: Fund demanders, which are composed of $N$ families of the same poor households; financial institution, which provides the poverty alleviation microcredit to the poor households (in $\mathrm{k}_{\mathrm{m}}$ ); and the government, which provides agricultural production and operation capital subsidies (in $\mathrm{k}_{\mathrm{s}}$ ) to poor households, such as fertilizers, seeds, and circulation of agricultural products, etc. Social relief, other than poverty alleviation microcredit, agricultural production, and operation capital subsidy, is recorded as $\tau_{t}$ : The time endowment of each poor household (standardized as 1 for the sake of simplicity) minus the labor time $\left(l_{t}\right)$ of agricultural production activities of each poor household in period $t$, then the leisure time of each poor household is $1-1_{t}$. Note that $\rho$ is the discount factor, $\mathrm{k}_{\mathrm{t}}$ is the capital investment of agricultural production and operation activities of poor households in period $t, a_{t}$ is the assets of poor households in period $t$, and $A$ is the agricultural production technology. Then, using the Cobb-Douglas production function to express the agricultural production activities of poor households, assuming that the agricultural production technology remains unchanged, the output in period $\mathrm{t}$ is:

$$
\mathrm{y}_{\mathrm{t}}=\mathrm{Ak}_{\mathrm{t}}^{\alpha} 1_{\mathrm{t}}^{1-\alpha}, 0<\alpha<1
$$

where $\alpha$ and $1-\alpha$ are the elasticities of output with respect to capital and labor. The real use cost of capital consists of three parts: First, the interest earned by abandoning the sale of capital and saving the income; second, the depreciation of capital; and third, the cost of capital price changes. Assuming that the capital price remains unchanged, the capital rent rate is $r_{t}$, the capital depreciation rate is $\delta_{t}$, and the opportunity cost of capital is $r_{t}+\delta_{t}$. Both the poverty alleviation microcredit $k_{m}$ and the agricultural production and operation capital subsidy $k_{s}$ are part of the capital input $k_{t}$ in the agricultural production of poor households. As the capital subsidy mainly includes the means for life and production [32], which is the free fund issued by the government, and the government subsidizes the interest on the poverty alleviation microcredit, $\mathrm{k}_{\mathrm{m}}$ and $\mathrm{k}_{\mathrm{s}}$ do not involve the capital cost. The capital use cost and net income of poor households in period $t$ are calculated as per Equations (2) and (3), respectively:

$$
\begin{gathered}
\mathrm{r}_{\mathrm{K}}(\mathrm{t})=\left(\mathrm{r}_{\mathrm{t}}+\delta_{\mathrm{t}}\right)\left(\mathrm{k}_{\mathrm{t}}-\mathrm{k}_{\mathrm{s}}-\mathrm{k}_{\mathrm{m}}\right), \\
\pi_{\mathrm{t}}=\mathrm{Ak}_{\mathrm{t}}^{\alpha} 1_{\mathrm{t}}^{1-\alpha}-\left(\mathrm{r}_{\mathrm{t}}+\delta_{\mathrm{t}}\right)\left(\mathrm{k}_{\mathrm{t}}-\mathrm{k}_{\mathrm{s}}-\mathrm{k}_{\mathrm{m}}\right) .
\end{gathered}
$$

The equation of period $t$ asset accumulation of poor households is as follows:

$$
\dot{a_{t}}=\pi_{t}+r_{t} a_{t}-c_{t}+\tau_{t}
$$

where $a_{t}$ refers to the assets of poor households, $r_{t} a_{t}$ is the interest income of the assets of poor households, and $c_{t}$ is the consumption of poor households in period $t$. Some studies showed that the rural financial market system is not perfect, the loan constraints are widespread, and the agricultural 
production input of poor households does not exceed the sum of their own assets, capital subsidies, or poverty alleviation microcredit funds. The loan constraint equation is expressed as:

$$
\mathrm{k}_{\mathrm{t}} \leq \mathrm{a}_{\mathrm{t}}+\mathrm{k}_{\mathrm{m}}+\mathrm{k}_{\mathrm{s}}
$$

Under the fixed conditions of capital subsidy and poverty alleviation microcredit, and under the restriction of lending constraint Equation (5), to maximize the income of poor households, the first-order derivation of $\mathrm{k}_{\mathrm{t}}$ in Equation (3) is carried out, and the optimal capital investment equation is:

$$
\mathrm{k}_{\mathrm{t}}=\min \left\{\left[\mathrm{A} \alpha /\left(\mathrm{r}_{\mathrm{t}}+\delta_{\mathrm{t}}\right)\right]^{1 /(1-\alpha)} 1_{\mathrm{t}}, \mathrm{a}_{\mathrm{t}}+\mathrm{k}_{\mathrm{m}}+\mathrm{k}_{\mathrm{s}}\right\},
$$

which shows that the higher the production technology A of poor households, the larger the elasticity of capital output $\alpha$, the greater the labor time $l_{t}$, the smaller the opportunity cost $r_{t}+\delta_{t}$, and the larger the capital input of poor households. The maximum value is the sum of their own assets, capital subsidies, and microcredit. The utility function of poor households is expressed as:

$$
\mathrm{U}=\mathrm{E}_{0} \int_{\mathrm{t}=0}^{\infty} \mathrm{e}^{-\rho \mathrm{\rho t}} \frac{\left[\mathrm{c}_{\mathrm{t}}\left(1-1_{\mathrm{t}}\right)^{\theta}\right]^{1-\sigma}}{1-\sigma} \mathrm{dt}, \sigma, \theta, \rho>0,
$$

where $\mathrm{E}_{0}$ is the zero period expectation operator, $\theta$ is the leisure utility parameter, and $\sigma$ is the coefficient of relative risk aversion.

Using the objective function in Equation (7), under the constraints of the net income in Equation (3) and the asset accumulation in Equation (4) of poor households in period $t$, the Hamiltonian function was constructed to derive the consumption $c_{t}$ and agricultural production labor time $l_{t}$ of poor households in the first order to maximize the expected utility. The first-order optimal condition is:

$$
\begin{gathered}
c_{t}^{-\sigma}\left(1-l_{t}\right)^{\theta(1-\sigma)}=\lambda_{t}, \\
\theta c_{t}^{1-\sigma}\left(1-l_{t}\right)^{\theta-\theta \sigma-1}=\lambda_{t}(1-\alpha){A k_{t}^{\alpha} 1_{t}^{-\alpha} .}^{-\alpha}
\end{gathered}
$$

According to the Ramsey-Keynes optimal saving rule, namely, the Euler equation, there are:

$$
\dot{\lambda_{t}} / \lambda_{\mathrm{t}}=\rho-\mathrm{r}_{\mathrm{t}}
$$

where $\lambda_{t}$ is Hamiltonian multiplier, which represents the shadow price of the assets of poor households. When utility is maximized, the marginal utility of consumption $c_{t}^{-\sigma}\left(1-1_{t}\right)^{\theta(1-\sigma)}$ is equal to the shadow price of assets $\lambda_{t}$. The marginal utility of leisure is $\theta c_{t}^{1-\sigma}\left(1-l_{t}\right)^{\theta-\theta \sigma-1}$, equal to the product of the marginal output of labor $(1-\alpha) \mathrm{Ak}_{\mathrm{t}}^{\alpha} 1_{\mathrm{t}}^{-\alpha}$ and the shadow price of assets $\lambda_{\mathrm{t}}$. The change rate of asset shadow price is equal to the actual discount rate $\rho-r_{t}$.

As the current conditions of the rural financial market mechanism and the credit demand are greater than the credit supply, the current financing mechanism cannot meet the demand of agricultural production and operation. In Equation (6), the upper limit of loan constraint $a_{t}+k_{m}+k_{s}$ should be less than the optimal capital input $\left[\mathrm{A} \alpha /\left(\mathrm{r}_{\mathrm{t}}+\delta_{\mathrm{t}}\right)\right]^{1 /(1-\alpha)} \mathrm{l}_{\mathrm{t}}$, then the agricultural production investment capital of poor households is:

$$
\mathrm{k}_{\mathrm{t}}=\mathrm{a}_{\mathrm{t}}+\mathrm{k}_{\mathrm{m}}+\mathrm{k}_{\mathrm{s}}
$$

When the economy reaches steady equilibrium, $\dot{\lambda_{t}}=\dot{a_{t}}=0$, and Equations (8)-(11) can obtain steady-state output:

$$
\mathrm{y}^{*}=\frac{\mathrm{A}(1-\alpha)\left[\mathrm{A} \alpha /\left(\mathrm{r}_{\mathrm{t}}+\delta_{\mathrm{t}}\right)\right]^{1 /(1-\alpha)}-\theta \tau+\theta\left(\rho \mathrm{k}_{\mathrm{m}}-\delta \mathrm{k}_{\mathrm{s}}\right)}{1+\theta-\alpha-\theta \delta \alpha(\rho+\delta)^{-1}}
$$


According to Equations (3) and (12), the net income of poor households in steady state can be obtained as follows:

$$
\pi^{*}=(1-\alpha) \mathrm{y}^{*}+(\rho+\delta) \mathrm{k}_{\mathrm{s}} .
$$

Based on the net income of the poor households in the steady-state equilibrium of the economy, the first-order derivations of the poverty alleviation microcredit $\mathrm{km}$ and the agricultural production and operation capital subsidy $\mathrm{k}_{\mathrm{s}}$ are carried out, respectively:

$$
\begin{gathered}
\partial \pi^{*} / \partial \mathrm{k}_{\mathrm{m}}=\theta \rho(1-\alpha) /\left[1+\theta-\alpha-\theta \delta \alpha(\rho+\delta)^{-1}\right], \\
\partial \pi^{*} / \partial \mathrm{k}_{\mathrm{s}}=[(1+\theta-\alpha)(\rho+\delta)-\theta \delta] /\left[1+\theta-\alpha-\theta \delta \alpha(\rho+\delta)^{-1}\right], \\
1+\theta-\alpha-\theta \delta \alpha(\rho+\delta)^{-1}>(1+\theta)(1-\alpha)>0 .
\end{gathered}
$$

The numerator and denominator of Equation (14) are both positive, so $\partial \pi^{*} / \partial \mathrm{k}_{\mathrm{m}}>0$; that is, the poverty alleviation microcredit can increase the net income of poor households because the poverty alleviation microcredit effectively alleviates the credit constraints faced by poor households, increases the investment in agricultural production capital and labor, and improves the effect of the poverty alleviation microcredit to increase income. The denominator in Equation (15) is positive but the molecular symbol is uncertain, so the effect of agricultural production and operation capital subsidy $k_{s}$ on the net income of poor households is not clear. The analysis shows that the poverty alleviation microcredit can increase the income of poor households, but it is not an inevitable phenomenon; instead, it is the result of certain conditions. For example, poor households are homogeneous, only engaged in agricultural production activities to obtain income, and their own assets, capital subsidies, and the poverty alleviation microcredit are all put into agricultural production activities. Then, what is the effect of the poverty alleviation microcredit on the income of poor households? In the following, we used micro-research data for empirical study.

We formulated three hypotheses. First, the poverty levels of poor households are different, and their own conditions are different. For poor households that are in poverty due to disability and in poverty due to illness, due to the lack of labor capacity, they cannot increase their income through independent labor, so they need to rely on social relief to overcome poverty. However, for poor households with insufficient endogenous development motivation, if the government directly distributes money and materials and provides free subsidies, they can only address their current production and living difficulties. If the aid is stopped, poverty conditions easily return; thus, "blood transfusion" poverty alleviation is not conducive to the sustainable development of poverty alleviation policies. The poverty alleviation microcredit is an important measure of financial poverty alleviation in China. It supports poor households in enlarge reproduction through financial subsidy interest, effectively solving the problem of investment funds for the development and production of poor households. It improves the endogenous power and self-development capacity of poor households, and expands the production scale. The poverty alleviation microcredit has a long-term effect on poverty alleviation and income increases, which is categorized as hematopoietic poverty alleviation [10]. However, various hypotheses state microfinance alleviates poverty, and poor households have insufficient demand for microfinance [15]. Therefore, we constructed hypothesis 1 :

Hypothesis 1 (H1). Excluding the influence of other factors, microcredit for poverty alleviation has a positive effect on the increase in income of poor households.

Second, the poverty alleviation microcredit alleviates the financial constraints on the development of poor households, stimulates the development momentum of these households, and enhances the ability of independent development. The marginally poor households can only maintain their current production and lifestyle due to their lack of funds or inability to bear business risks. If they are provided with credit funds with repayment expectations, their ability and courage to expand their 
production and business scale can be increased [33]. However, those poor households that are at the lowest income level, and that lack effective demand for loans and have the ability to work, find it difficult to effectively use credit services [16]. The poverty alleviation microcredit policy requires that it should be used precisely for the development and production of poor households, and the investment industry and projects have certain market mechanisms to prevent and resolve risks and avoid the excessive debt of poor households. With regard to whether poor households with a lack of funds can increase their income to realize their long-term benefits, we formulated hypothesis 2 :

Hypothesis 2 (H2). The poverty alleviation microcredit significantly affects the increase in the income of households that are poor due to lack of funds.

Third, the main recipient of microcredit is women [31]. Microcredit can empower women and improve their social status. Women better use microcredit and have a higher capital use rate. In addition, they can meet their demand for production development and increase income, and thus improve their social status [34-36]. However, other studies found that microcredit has no significant impact on women's empowerment [37]. Therefore, hypothesis 3 is proposed:

Hypothesis 3 (H3). The effect of the poverty alleviation microcredit is significant for poor households whose heads are women.

Based on the above analysis of the theoretical framework of the poverty alleviation microcredit to increase the income of poor households, the following empirical research was combined with field survey data.

\section{Research Design}

\subsection{Empirical Approach}

There are some difficulties in evaluating the impact of credit on the income of poor households as the following. First, the endogenous problem of loan cannot be avoided. The credit behavior depends on the interaction between the supply of the bank and the demand of the poor households. Under the influence of the poverty alleviation microcredit policy, credit and the loan amount are not random. Whether or not the loan and the amount of loan exist self-selection. It is difficult to judge whether the estimated credit effect is the credit constraint or the influence of the borrower's unobservable factors. If the borrower's self-selection feature is not properly treated, the selectivity deviation may reach $100 \%$. Second, the effect of credit on the poor households with different income levels is heterogeneous. The poor households with income near the poverty line and deep poverty have different abilities. The efficiency of credit utilization is different, which makes the estimation more complicated. In the aspect of loan income effect research, the Instrumental Variable Quantile Regression (IVQR) model [38-40], Tobit model [41], random effect model [42], fixed effect model, and instrumental variable method have been used. [43-45]. Many models fail to solve the problem of farmers' self-selection. In addition, there are many limitations in the selection and use of these models. There are also many requirements in the form of functions and the distribution of error items. It is also difficult to select tool variables. In order to estimate the impact of the poverty alleviation microcredit policy, this paper compares the income difference of the poor households before and after the implementation of the policy. The income difference is affected by many factors, so it is necessary to eliminate the interference of other factors. In addition, poor households decide whether to apply for and use loans according to the expected benefits of poverty alleviation microcredit, which complicates the estimation of the average treatment effect on the treated (ATT), and it is impossible to observe the income situation of poor households before they have received poverty alleviation microcredit. Therefore, we used propensity score matching (PSM) proposed by Rosenbaum and Rubin [46]. The advantage of PSM model is that it not only solves the problem of selection bias and 
biased estimate caused by "self-selection" of samples, but also solves the problem of many limitations in the use of other models when dealing with the endogenous problem of variables. The sample data were divided into an experimental group (poor households receiving poverty alleviation microcredit) and a control group (those not receiving poverty alleviation microcredit), and the samples from the two groups were matched one-to-one according to the matching principle so that the characteristics of the samples from both groups were the same, which ultimately maximized the control of the sample heterogeneity of both groups and separated the income changes caused by the poverty alleviation microcredit from other factors. We then simulated the counter-factual state, then comparatively studied the impact of poverty reduction microcredit on poor household's income increase, and generated a reasonable assessment of the effect of the poverty alleviation microcredit policies.

The logit model was used to screen the variables that affect the credit of poor households, select the main variables that affect the credit of these households, and calculate the propensity score (P_score); that is, the conditional probability of poor households to obtain the poverty alleviation microcredit under the condition of a given sample observable characteristic $X$ and to reduce the dimension of matching standard:

$$
p\left(X_{i}\right)=P_{r}\left(D_{i}=1 \mid X_{i}\right)=\frac{\exp \left(\beta X_{i}\right)}{1+\exp \left(\beta X_{i}\right)^{\prime}}
$$

where $\frac{\exp (\cdot)}{1+\exp (\cdot)}$ represents the cumulative distribution function of logical distribution; $X_{i}$ is the multidimensional vector, which represents the individual characteristics of the sample (matching variable); and $D_{i}$ is the virtual variable of the policy: If the poor households received poverty alleviation microcredit, the value is 1 ; otherwise, it is $0 . \beta$ is the corresponding parameter variable and $i$ is the poor individual. The probability value $\hat{p}\left(X_{i}\right)$ of a poor household's access to the poverty alleviation microcredit can be obtained by calculating the parameter estimation value of Equation (18); that is, the propensity score of poor households' access to the poverty alleviation microcredit in the sample. The ith poor household's propensity score is $\mathrm{p}\left(\mathrm{X}_{\mathrm{i}}\right)$, and the ATT of their access to the poverty alleviation microcredit can be expressed as follows:

$$
\begin{aligned}
\text { ATT } & =E\left[Y_{1 i}-Y_{0 i} \mid D_{i}=1\right]=\left\{E\left[Y_{1 i}-Y_{0 i} \mid D_{i}=0, p\left(X_{i}\right)\right]\right\} \\
& =E\left\{E\left[Y_{1 i} \mid D_{i}=1, p\left(X_{i}\right)\right]-E\left[Y_{0 i} \mid D_{i}=0, p\left(X_{i}\right)\right] \mid D_{i}=1\right\} \\
& =\frac{1}{N^{T}} \sum_{i \in T} Y_{i}^{T}-\frac{1}{N^{T}} \sum_{j \in C} \lambda\left(p_{i}, p_{j}\right) Y_{j}^{C},
\end{aligned}
$$

where $Y_{1 i}$ refers to the income of poor households receiving the poverty alleviation microcredit and $\mathrm{Y}_{0 \mathrm{i}}$ refers to the income of poor households not receiving poverty alleviation microcredit. Suppose that in the case given by $X_{i},\left(Y_{0 i}, Y_{1 i}\right)$ is independent of $D_{i}$, and the mean values of $Y_{1 i}$ and $Y_{0 i}$ are independent of $D_{i} \cdot N^{T}$ is the sample number of poor households that received poverty alleviation microcredit; $T$ is the experimental group after matching; $C$ is the control group before matching; $Y_{i}^{T}$ is the ith observation result of the control group that has obtained poverty alleviation microcredit; $Y_{j}^{C}$ is the jth observation result of the control group that has not obtained poverty alleviation microcredit; $p_{i}$ is the prediction probability value of the ith poor households in the experimental group; $p_{j}$ is the prediction probability value of the $\mathrm{jth}$ poor households in the control group; and $\lambda\left(\mathrm{p}_{\mathrm{i}}, \mathrm{p}_{\mathrm{j}}\right)$ is the weight function of $p_{i}$ and $p_{j}$. Three matching methods can be used to obtain the ATT: k-nearest neighbor matching, radius matching, and kernel matching. Different methods have different weight functions. By substituting the result of Equation (17) into Equation (18), we can determine the impact of the poverty alleviation microcredit on the income of poor households.

Because $\mathrm{p}\left(\mathrm{X}_{\mathrm{i}}\right)$ is a continuous variable, it is difficult to find two samples with an identical P_score, which complicated the matching between the experimental group and the control group. In this study, we first used the k-nearest neighbor matching method, which is widely used in the literature, and then used radius matching and kernel matching to test the robustness. The k-nearest neighbor matching finds the sample closest to the score of the experimental group in the control group according to the P_score of the experimental group sample, which then forms a pair. Finally, the effect of access to 
the poverty alleviation microcredit was then evaluated on the income of poor households. PSM can control the sample selection bias and endogeneity when no difference exists in the mean value of the basic period variables between the two sample groups, and can estimate ATT to determine the real effect of the poverty alleviation microcredit policy.

\subsection{Sample and Data}

The data used in this article were obtained from the survey data we collected when conducting home visits to three provinces in central China in 2019. The survey implemented a multistage random cluster design in three provinces, including 200 villages from 20 counties. In those sample villages, the research team conducted questionnaire surveys with randomly picked 20-30 poor households whose information was filed in the poverty-stricken household database regarding the poverty alleviation microcredit. A total of 4400 questionnaires were obtained from the investigative research, of which 4198 were valid after inputting, sorting, and screening all the information. According to the provisions of the poverty alleviation microcredit policy, the loan provided to the poor households is used for the development of production, and the loan term is within three years. Therefore, this paper selects the poor households that use all the loans for the development of production and operation activities, and are still within the loan term in 2018 (i.e., obtain loans between 2015 and 2018) as the sample of poverty alleviation microcredit. Of the 4198 valid questionnaires, 677 were from poor households that had received the poverty alleviation microcredit and 3521 from poor households that had not. "Poor households" in this study refer to the poverty-stricken households that have been accurately identified and registered in the poverty alleviation database. Since the poor households that have been lifted out of poverty can still enjoy policy assistance, the poor households here include both the ones who are out of poverty and those who are not yet.

The basic characteristics of the sampled poor households are described in Table 1. The number of the heads of households aged 50-59 years old in the group (1), (3), (4), and (5) is the most. Male heads in group (1) and (2) is more than female heads. Female heads in group (3) and (4) is more than male heads. The poor households in the group (1)-(6) are the most, whose proportion of the family labor force in total family members accounts for $25-50 \%$. There are many poor households with agricultural insurance coverage $100 \%$ of the sample, that is the area of insured crops is equal to the area of insurable crops and the number of insured livestock equals the number of insurable livestock. In control groups, there are lots of the poor households who did not have agricultural insurance. The annual household production income of many poor households who obtained the poverty alleviation microcredit is mainly concentrated in 10,000-50,000 yuan in 2018. The annual household production income of many poor households without the poverty alleviation microcredit was less than 3000 yuan in 2018. The number of the sample households in all groups are the poor households with annual household production expenditure less than 3000 yuan in 2018 is the most. A few sample households were poverty-stricken due to the lack of capital in the group (1), (2), (5), and (6).

\subsection{Variable Selection and Descriptive Statistics}

Combining the theoretical framework with existing research, we took the production income of the poor households as the outcome variable, and selected eight matching variables including: First, the basic characteristics of the poor households, i.e., sex, age, and causes of poverty. The education level in poor households is generally low, and in agricultural production activities, the members of the entire family have the ability to work jointly to use poverty alleviation microcredit. Therefore, we did not use the educational level of the head of household as a control variable for empirical analysis. Second is the family characteristics of poor households, including the total family number of households and the number of laborers. Third is the poor households' access to poverty alleviation microcredit, that is, whether they received the poverty alleviation microcredit or not. Fourth is the poor households' production, i.e., annual household production expenditure, agricultural insurance coverage. The selection and descriptions of specific variables are shown in Table 2. 
Table 1. Basic characteristics of the heads of poor households and their families.

\begin{tabular}{|c|c|c|c|c|c|c|c|}
\hline \multirow{2}{*}{\multicolumn{2}{|c|}{ Variable and Categories }} & \multicolumn{2}{|c|}{ Overall Sample } & \multicolumn{2}{|c|}{$\begin{array}{c}\text { Samples of Poverty } \\
\text { Caused by Lack of Funds }\end{array}$} & \multicolumn{2}{|c|}{$\begin{array}{c}\text { Samples of Female Heads } \\
\text { of Households }\end{array}$} \\
\hline & & $\begin{array}{c}\text { Experimental } \\
(1) \\
\end{array}$ & $\begin{array}{c}\text { Control } \\
(2) \\
\end{array}$ & $\begin{array}{c}\text { Experimental } \\
(3)\end{array}$ & $\begin{array}{c}\text { Control } \\
(4)\end{array}$ & $\begin{array}{c}\text { Experimental } \\
(5) \\
\end{array}$ & $\begin{array}{c}\text { Control } \\
(6)\end{array}$ \\
\hline \multirow{3}{*}{$\begin{array}{l}\text { The age of the } \\
\text { head of a poor } \\
\text { household }\end{array}$} & 30 and below & 2 & 27 & 0 & 1 & 1 & 14 \\
\hline & 30-39 & 41 & 159 & 12 & 26 & 17 & 84 \\
\hline & 60 and above & 132 & 1697 & 19 & 107 & 48 & 764 \\
\hline \multirow{2}{*}{$\begin{array}{l}\text { The sex of the } \\
\text { head of a poor } \\
\text { household }\end{array}$} & Male & 386 & 1856 & 50 & 151 & - & - \\
\hline & Female & 291 & 1665 & 54 & 170 & - & - \\
\hline $\begin{array}{l}\text { Proportion of } \\
\text { family labor } \\
\text { force in total } \\
\text { family members }\end{array}$ & $0-25 \%$ & 43 & 1052 & 3 & 32 & 16 & 454 \\
\hline \multirow{5}{*}{$\begin{array}{l}\text { Agricultural } \\
\text { insurance } \\
\text { coverage }\end{array}$} & $0-25 \%$ & 3 & 21 & 0 & 0 & 3 & 12 \\
\hline & $25-50 \%$ & 32 & 147 & 3 & 10 & 7 & 89 \\
\hline & $50-75 \%$ & 27 & 40 & 4 & 11 & 8 & 18 \\
\hline & $75-100 \%$ & 22 & 92 & 4 & 11 & 5 & 55 \\
\hline & $100 \%$ & 449 & 1259 & 70 & 123 & 195 & 537 \\
\hline \multirow{5}{*}{$\begin{array}{l}\text { Household } \\
\text { production } \\
\text { Income in } 2018\end{array}$} & 0-3000 yuan & 87 & 1705 & 11 & 130 & 36 & 806 \\
\hline & $3000-5000$ yuan & 76 & 409 & 14 & 34 & 31 & 215 \\
\hline & $5000-10,000$ yuan & 138 & 670 & 24 & 74 & 60 & 309 \\
\hline & $10,000-50,000$ yuan & 282 & 670 & 44 & 79 & 130 & 310 \\
\hline & $\begin{array}{l}50,000 \text { yuan and } \\
\text { above }\end{array}$ & 94 & 67 & 11 & 4 & 34 & 25 \\
\hline $\begin{array}{l}\text { Poverty caused } \\
\text { by lack of funds }\end{array}$ & No & 573 & 3200 & - & - & 237 & 1495 \\
\hline
\end{tabular}

Table 2. Descriptive statistical results of the variables.

\begin{tabular}{|c|c|c|c|c|c|}
\hline \multirow{3}{*}{ Variable } & \multirow{3}{*}{ Description } & \multicolumn{2}{|c|}{ Experimental } & \multicolumn{2}{|c|}{ Control } \\
\hline & & Mean & SD & Mean & SD \\
\hline & & (7) & (8) & (9) & (10) \\
\hline income & $\begin{array}{l}\text { The income obtained by a poor household } \\
\text { through production and operation activities in } \\
\text { 2018, such as agriculture, industry, etc. (yuan) }\end{array}$ & 22,210 & $33,753.12$ & 6471 & $13,521.00$ \\
\hline age & Actual age of the head of a poor household & 52.98 & 9.26 & 58.79 & 12.29 \\
\hline $\operatorname{sex}$ & $\begin{array}{l}\text { Sex of the head of a poor household }(\text { male }=1 ; \\
\text { female }=0)\end{array}$ & 0.57 & 0.50 & 0.53 & 0.50 \\
\hline family & $\begin{array}{c}\text { Total number of family members of a poor } \\
\text { household }\end{array}$ & 4.29 & 1.46 & 3.39 & 1.75 \\
\hline labor & $\begin{array}{l}\text { The number of a poor household aged } 16 \text { to } 60 \\
\text { who are able to work, except for students }\end{array}$ & 2.50 & 1.08 & 1.58 & 1.23 \\
\hline expend & $\begin{array}{l}\text { Production Expenditure of poor households in } \\
2018 \text { (yuan) }\end{array}$ & 8739 & $22,251.15$ & 2144 & 6500.07 \\
\hline Ari_Ins & $\begin{array}{c}\text { Proportion of agricultural insurance coverage of } \\
\text { a poor household }(\%)\end{array}$ & 74 & 40.81 & 41 & 47.37 \\
\hline reason & Poverty caused by lack of funds (yes $=1$; no $=0$ ) & 0.15 & 0.36 & 0.09 & 0.29 \\
\hline
\end{tabular}

As seen from columns (7) and (8) in Table 2, the average annual household production income of the experimental group in 2018 was 22,210 yuan, and the average annual household production 
expenditure of poor households in 2018 was 8739 yuan. The average proportion of agricultural insurance coverage is $74 \%$. The heads of $57 \%$ of the sample in the experimental group were male family members. The average age of the poor individuals was 53 years old, while the average family size was four persons, and the average number of laborers in one family was two or three. Of the families, $15 \%$ were poverty-stricken due to the lack of capital. In columns (9) and (10) in Table 2, the average annual household production income of the control group in 2018 was 6471 yuan, and the average annual household production expenditure of poor households in 2018 was 2144 yuan. The average proportion of agricultural insurance coverage is $41 \%$. The heads of $53 \%$ of sample in the experimental group were male family members. The average age of the poor individuals was 59 years old, while the average family size was four persons, and the average number of laborers in one family was two or three. Of the families, $9 \%$ were poverty-stricken due to the lack of capital.

\section{Results}

According to the propensity matching scoring method (PSM), combined with the guidance for the implementation of PSM [47], first, the logit model was used to estimate the probability of poor households receiving poverty alleviation microcredit, and then a balance test was performed, in which whether or not poor households who had obtained the poverty alleviation microcredit was used as an explanatory variable; those that had were marked as one, and those that had not as zero. The attributes of poor households, including sex, age, total number of family members, family labor force, cause of poverty, annual household production expenditure, and proportion of agricultural insurance coverage, were used as control variables. The propensity scores of the poor households for receiving the poverty alleviation microcredit were estimated, and then a balance test between the experimental group and the control group was conducted. Secondly, given the probability of obtaining microcredit, the three methods, k-nearest neighbor matching, radius matching, and kernel matching, were used to calculate the ATT of poverty alleviation microcredit. Sample matching between those who obtained microcredit and those who had not was conducted, and the impact of the poverty alleviation microcredit on production income was estimated to reduce the selection biases. Finally, a robustness test was performed on the model and the estimated results.

\subsection{Propensity Score Estimation}

We adopted the logit model to estimate propensity scores, selected the main factors that affect the ability of the poverty-stricken households to obtain microcredit, and used the corresponding predicted values as the propensity scores of poor households to obtain poverty alleviation microcredit. The estimated propensity scores of the matching variables are shown in Table 3. Among the selected variables, except for the variable of "sex of the head of a poor household" and "the total number of family members of the poor households", all other variables showed significant effects on poor households' access to poverty alleviation microcredit, including the age of the head of a poor household, the number of labor force of a poor household, annual household production expenditure, proportion of agricultural insurance coverage, and causes of poverty.

Except for the variable of "causes of poverty" that has a significant positive effect at the $5 \%$ level, the other four variables showed significant effects at the $1 \%$ level. First, the age of the head of poor households had a significant positive effect on poor households' access to the poverty alleviation microcredit at the $1 \%$ level. Variable ageaq (age square), had a significant negative effect at the $1 \%$ level, indicating that within a certain age range, the older the heads of the poor household, the easier it was to obtain poverty alleviation microcredit. Influenced by the traditional concept, the older poor households are relatively conservative in loan financing, and generally use their own funds for production activities. In addition, the older poor households have relatively low education level, while the younger poor households lack life experience, so they are unable to effectively use loan [27]. Second, the number of labor members of poor families had a significant positive impact on poor households' access to poverty alleviation microcredit. People with labor ability can invest more labor intensity and more labor time 
in production activities, and create more labor value, which is the backbone force for poor families to obtain production income. Third, the production expenditure has a significant positive impact on poor households' access to poverty alleviation microcredit. The larger the scale of agricultural operation, the stronger the financial demand. Fourth, the proportion of agricultural insurance has a significant positive impact on poor households' access to poverty alleviation microcredit. Due to the high risk of natural conditions and price of agricultural products, agricultural insurance can promote investment behavior of agricultural production technology, and stabilize the expected income of farmers [48-51]. Fifth, the cause of poverty has a significant positive impact on poor households' access to poverty alleviation microcredit. Due to the lack of development and operation funds, some poor households have low household income. The poverty alleviation microcredit is a targeted poverty alleviation policy to meet the credit needs of the poor, improve the production and living conditions of poor households, and help them increase income. However, the sex of the head of a poor household and total number of family members of a poor household did not have a significant impact on their access to poverty alleviation microcredit. The possible reasons include: The poverty alleviation microcredit applied by the heads of poor households is jointly used by family members in the development of production, so the relationship between access to credit and the sex of the head of poor household is not obvious. Besides, for poor families with a large population, most of the members are elderly or children who cannot provide effective labor and have a relatively higher cost of living, which means the household's ability to repay the loans is limited. Therefore, the sex of the head of a poor household and total number of family members of a poor household did not play an important role in affecting whether the poor household can obtain poverty alleviation microcredit. Therefore, this paper chose five variables for matching: The age of the heads of the poor households, the number of labor force of the poor households, the production expenditure, proportion of agricultural insurance coverage of the poor households, and poverty caused by lack of funds.

Table 3. The propensity score estimation results of matching variables.

\begin{tabular}{|c|c|c|}
\hline \multirow{2}{*}{ Variable } & \multirow{2}{*}{ Description } & \multirow{2}{*}{$\begin{array}{c}\text { P-Score: Logit Regression } \\
\text { (11) }\end{array}$} \\
\hline & & \\
\hline age & Actual age of the head of a poor household & $\begin{array}{l}0.11^{* * *} \\
(2.95)\end{array}$ \\
\hline sex & Sex of the head of a poor household $($ male $=1 ;$ female $=0)$ & $\begin{array}{c}0.15 \\
(1.60)\end{array}$ \\
\hline family & Total number of family members of a poor household & $\begin{array}{c}0.00 \\
(0.07)\end{array}$ \\
\hline labor & $\begin{array}{c}\text { The number of a poor household aged } 16 \text { to } 60 \text { who are able to work, } \\
\text { except for students }\end{array}$ & $\begin{array}{l}0.40^{* * *} \\
(7.34)\end{array}$ \\
\hline expend & Production Expenditure of poor households in 2018 (yuan) & $\begin{array}{l}0.00^{* * *} \\
(7.40)\end{array}$ \\
\hline ari_ins & $\begin{array}{l}\text { Proportion of agricultural insurance coverage of a poor household } \\
\qquad(\%)\end{array}$ & $\begin{array}{l}0.01^{* * *} \\
(11.88)\end{array}$ \\
\hline reason & Poverty caused by lack of funds (yes $=1 ;$ no $=0$ ) & $\begin{array}{l}0.35^{* * *} \\
(2.58)\end{array}$ \\
\hline ageaq & Ageaq $=$ age $\times$ age & $\begin{array}{l}-0.00 * * * \\
(-3.70)\end{array}$ \\
\hline incomesq & Incomesq $=$ income $\times$ income & $\begin{array}{l}-0.00 * * * \\
(-2.57)\end{array}$ \\
\hline
\end{tabular}

Note: T-statistics in parenthesis. ${ }^{* * *}$ Parameters statistically different from 0 at the $1 \%$ probability level.

\subsection{Balance Test}

We tested the matching balance between the experimental group and the control group of the all sample. Table 4 shows the results of the error elimination of the main variables, which were generated after using the k-nearest-neighbor matching method to evaluate and match the income 
impact of microcredit on the poor households. Compared with the mean before matching, the standard deviations of most of matching variables were less than $10 \%$. Most $t$-test results did not reject the original hypothesis that there was no systematic difference between the experimental group and the control group. Only one variable, expend, was found to have a systematic relationship between the experimental and control groups. After matching, the standard deviations of each variable decreased considerably, suggesting that the individual differences between the experimental group and the control group were partially eliminated. The standard deviations both before and after matching are shown in Figure 1, indicating that the differences decreased between the experimental group and the control group after matching.

Table 4. Balance test of k-nearest neighbor matching.

\begin{tabular}{ccccccccc}
\hline \multirow{2}{*}{ Variable } & \multicolumn{2}{c}{ Mean before Matching } & \multicolumn{2}{c}{ Mean after Matching } & \multirow{2}{*}{ \% Bias } & \multicolumn{2}{c}{$\boldsymbol{t}$-Test } \\
\cline { 2 - 5 } & Experimental & Control & Experimental & Control & & $\boldsymbol{t}$ & $\boldsymbol{p} \boldsymbol{t} \boldsymbol{t}$ \\
\hline age & 52.98 & 58.79 & 52.98 & 52.60 & 3.50 & 0.72 & 0.47 \\
sex & 0.57 & 0.53 & 0.57 & 0.60 & -5.00 & -0.92 & 0.36 \\
family & 4.29 & 3.39 & 4.29 & 4.44 & -8.90 & -1.68 & 0.09 \\
labor & 2.50 & 1.58 & 2.50 & 2.57 & -5.90 & -1.11 & 0.27 \\
expend & 8738.40 & 2144.40 & 8738.40 & 6007.90 & 16.70 & 2.53 & 0.01 \\
age_ins & 74.18 & 40.76 & 74.18 & 77.23 & -6.90 & -1.40 & 0.16 \\
reason & 0.15 & 0.09 & 0.15 & 0.16 & -0.60 & -0.09 & 0.93 \\
\hline
\end{tabular}

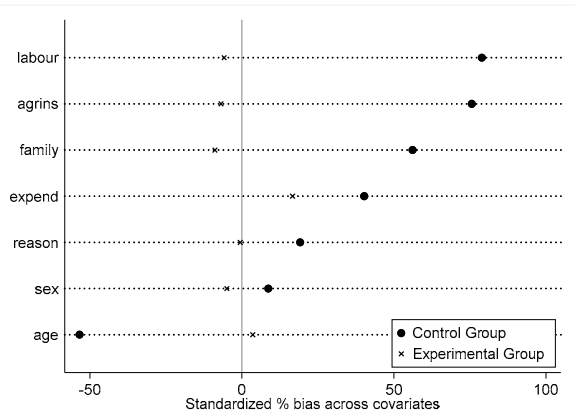

Figure 1. Standard deviation of the covariates before and after matching.

Figure 2 depicts a distribution map of poor households' propensity scores in the experimental and control groups. The figure shows that 20 sets were matched according to the propensity scores of the experimental and control groups, and each set was a temporary interval. The matching results of the experimental and control groups in terms of the propensity scores appear to be quite accurate, as most observed values are within the common value range, and the number of samples lost during the process of propensity score matching is small. The deviation between the average effect of the treatment on the treated estimated by the matching method and the estimated result obtained from random samples was small.

\subsection{Income Increase Effect of the Poverty Alleviation Microcredit Policy}

We used radius matching, k-nearest neighbor matching, and kernel matching to calculate the ATT of the poverty alleviation microcredit in three sample groups: All poor households, those whose poverty was caused by a lack of production funds, and those whose heads were women. The results after calculation are shown in Table 5. All three matching methods generated quite similar conclusions and most of the results passed the significance test at the $1 \%$ level. Only when the head of household is female, the average treatment effect after matching is significant at the level of $5 \%$. The matching results indicate the positive effect of the poverty alleviation microcredit on the production income increase of poor households. Take the radius matching method as an example: 
First, the poverty alleviation microcredit had a positive effect on the production income increase of the entire sample production. Before the sample matching, the average production income of poor households receiving the poverty alleviation microcredit and poor households not the receiving poverty alleviation microcredit in 2018 were 22,210 yuan and 6471 yuan, respectively, a difference of 15,739 yuan. After the samples were matched, the average production income of the two groups of poor households in 2018 was 20,015 yuan and 13,979 yuan, respectively, with a difference of 6036 yuan, a decrease of 9703 yuan compared with that before the matching. That is, the production income of poor households after receiving the poverty alleviation microcredit was increased by 6036 yuan compared with that before the loans were issued. This shows that for all of the sampled poor households, the income can be increased if they obtain the poverty alleviation microcredit and use it in the production activities. Therefore, hypothesis 1 is supported. Excluding the influence of other factors, the poverty alleviation microcredit has a positive effect on the increase in production income of poor households.

Second, the poverty alleviation microcredit had a positive effect on the production income increase of those who were poor due to a lack of funds. Before the sample matching, the average production incomes of poor households receiving the poverty alleviation microcredit and poor households not receiving the poverty alleviation microcredit in 2018 were 22,258 yuan and 7200 yuan, respectively, a difference of 15,058 yuan. After the samples were matched, the average production income of the two groups of poor households in 2018 was 15,557 yuan and 7935 yuan, respectively, with a difference of 7622 yuan, a decrease of 7436 yuan compared with that before the matching. That is, the production income of poor households after receiving the poverty alleviation microcredit was increased by 7622 yuan compared with before the loans were issued. This shows that for the sampled poor households that were poor due to a lack of funds, the income can be increased if they obtain the poverty alleviation microcredit and use it in production activities. Therefore, hypothesis 2 is supported. Excluding the influence of other factors, the poverty alleviation microcredit has a positive effect on the increase in production income of poor households that were poverty-stricken due to the lack of capital.

Third, the poverty alleviation microcredit had a positive effect on the production income increase of those poor households whose heads were female. Before the sample matching, the average production incomes of poor households receiving the poverty alleviation microcredit and poor households not receiving the poverty alleviation microcredit in 2018 were 21,922 yuan and 6168 yuan, respectively, a difference of 15,754 yuan. After the samples were matched, the average production income of the two groups of poor households in 2018 was 18,342 yuan and 10,355 yuan, respectively, with a difference of 7987 yuan, a decrease of 7767 yuan compared with that before the matching. That is, the production income of poor households in this sample group after receiving the poverty alleviation microcredit was increased by 7987 yuan compared with that before the loans were issued. This shows that for the sampled poor households whose heads were female, the income can be increased if they obtain the poverty alleviation microcredit and use it in production activities. Therefore, Hypothesis 3 is accepted. That is, excluding the influence of other factors, the poverty alleviation microcredit has a positive effect on the increase in production income of poor households whose heads are female.

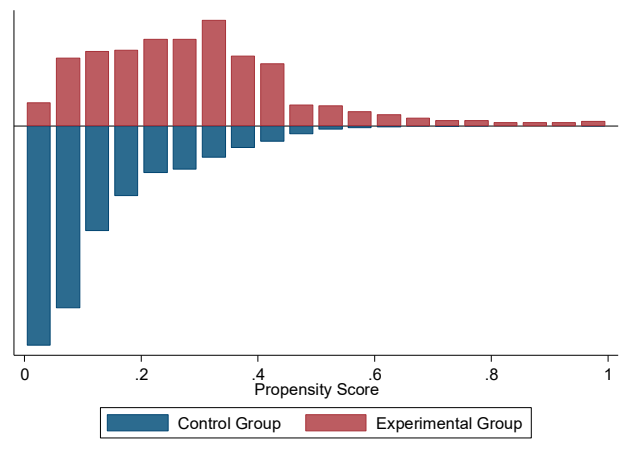

Figure 2. Distribution of sample propensity score matching. 
Table 5. The effects of the poverty alleviation microcredit policy on the production income of poor households.

\begin{tabular}{|c|c|c|c|c|c|c|}
\hline & Sample & & Experimental & Control & Difference & $t$-Stat \\
\hline \multirow{6}{*}{$\begin{array}{l}\text { Radius } \\
\text { matching }\end{array}$} & \multirow{2}{*}{ Overall sample } & unmatched & 22,210 & 6471 & 15,739 & $20.43^{* * *}$ \\
\hline & & matched & 20,015 & 13,979 & 6036 & $5.28^{* * *}$ \\
\hline & \multirow{2}{*}{$\begin{array}{l}\text { Samples of poverty } \\
\text { caused by lack of funds }\end{array}$} & unmatched & 22,258 & 7200 & 15,059 & $4.86^{* * *}$ \\
\hline & & matched & 15,557 & 7935 & 7622 & $3.99 * * *$ \\
\hline & \multirow{2}{*}{$\begin{array}{c}\text { Samples of female heads } \\
\text { of households }\end{array}$} & unmatched & 21,922 & 6168 & 15,754 & $12.99 * * *$ \\
\hline & & matched & 18,342 & 10,355 & 7987 & $5.36^{* * *}$ \\
\hline \multirow{6}{*}{$\begin{array}{l}\text { K-nearest } \\
\text { neighbor } \\
\text { matching }\end{array}$} & \multirow{2}{*}{ Overall sample } & unmatched & 22,210 & 6471 & 15,739 & $20.43^{* * *}$ \\
\hline & & matched & 21,607 & 15,835 & 5771 & $4.37^{* * *}$ \\
\hline & \multirow{2}{*}{$\begin{array}{l}\text { Samples of poverty } \\
\text { caused by lack of funds }\end{array}$} & unmatched & 22,258 & 7200 & 15,059 & $4.86^{* * *}$ \\
\hline & & matched & 15,176 & 13,123 & 2053 & $0.74^{* * *}$ \\
\hline & \multirow{2}{*}{$\begin{array}{c}\text { Samples of female heads } \\
\text { of households }\end{array}$} & unmatched & 21,922 & 6168 & 15,754 & $12.99 * * *$ \\
\hline & & matched & 17,980 & 13,892 & 4087 & $2.48^{* *}$ \\
\hline \multirow{6}{*}{$\begin{array}{l}\text { Kernel } \\
\text { matching }\end{array}$} & \multirow{2}{*}{ Overall sample } & unmatched & 22,210 & 6471 & 15,739 & $20.43^{* * *}$ \\
\hline & & matched & 21,607 & 16,373 & 5233 & $4.31^{* * *}$ \\
\hline & \multirow{2}{*}{$\begin{array}{l}\text { Samples of poverty } \\
\text { caused by lack of funds }\end{array}$} & unmatched & 22,258 & 7200 & 15,059 & $4.86^{* * *}$ \\
\hline & & matched & 18,300 & 7981 & 10,319 & $3.93^{* * *}$ \\
\hline & \multirow{2}{*}{$\begin{array}{l}\text { Samples of female heads } \\
\text { of households }\end{array}$} & unmatched & 21,922 & 6168 & 15,754 & $12.99 * * *$ \\
\hline & & matched & 19,164 & 11,965 & 7199 & $4.61^{* * *}$ \\
\hline
\end{tabular}

Note: ** Parameters statistically different from 0 at the $5 \%$ probability level. ${ }^{* * *}$ Parameters statistically different from 0 at the $1 \%$ probability level.

\section{Discussion and Conclusions}

We used the micro-survey data of 4198 poor households in central China to systematically study the effect of the poverty alleviation microcredit policies on the production income of poor households through the logit model and the propensity score matching method. The research analysis showed that important factors affecting poor households' possibility to receive the poverty alleviation microcredit include: The age of the heads of poor households, the number of family laborers, production expenditure of poor households, proportion of agricultural insurance coverage of poor households, and the lack of funds as one of the poverty causes. The results showed that the production income of all the sampled poor households after receiving the poverty alleviation microcredit was increased by 6036 yuan, the production income of poor households that were poor due to a lack of funds after receiving the poverty alleviation microcredit was increased by 7622 yuan, and the production income of poor households whose heads were female after receiving the poverty alleviation microcredit was increased by 7987 yuan. The main reasons why the poverty alleviation microcredit helps the poor households to increase their production income are as follows: Firstly, the microcredit can alleviate financial exclusion, to help the poor to resist economic shocks, enhance risk resistance, significantly improve the anti-poverty ability of the poor, and help them out of poverty in the long term $[52,53]$. On the one hand, the microcredit provides poor households with capital to purchase fixed assets, expand production scale, innovate technology, improve labor productivity, and increase income. If other conditions remain unchanged, it is possible to increase expenditure on children's education, nutrition, health, and leisure, and ultimately reduce poverty. On the other hand, access to loans reduces income volatility, which will alleviate poverty $[7,8,54-58]$. Secondly, through the "trickle effect" and income distribution effect of economic growth, the microcredit improves the income and living standard of poor families and indirectly alleviates poverty [59-63].

Based on the above conclusions, in order to further promote poor households to develop production, improve income, shake off poverty for long-term, and achieve the goal of poverty alleviation of the rural poor under the current standard in 2020, from a long-term perspective, this paper puts forward the following policy implications on the poverty alleviation microcredit policy: First, the poverty alleviation microcredit played an important role in supporting poor households to develop agricultural production 
and to increase their income. In order to eliminate poverty, we should continue to implement the poverty alleviation microcredit policy and increase the share of the poverty alleviation microcredit in the total loans of farmers. Second, agricultural production insurance should be vigorously promoted, along with improving the supporting measures for the poverty alleviation microcredit, enhancing the protection and strength, transferring the risks of agricultural production and operation, increasing the production income of poor households, and raising the credit repayment rate of financial institutions. Third, capital subsidies should be increased for agricultural production, and large-scale production should be encouraged. Most agricultural production is small scale with a low production efficiency and weak ability to resist risks. Through the issuance of capital subsidies for agricultural production and operation, poor households could be guided to jointly and uniformly produce, process, transport, and sell agricultural products. This would help to achieve scale effects and effective resource allocation, which leads to an income increase for poor households. This paper holds that capital investment is an important factor for poor households to develop agricultural production. At the same time, it should be supplemented by relevant supporting measures to establish a support mechanism to further improve the efficiency of the poverty alleviation microcredit policy and to reduce poverty through an income increase for poor households.

This study has some limitations. For instance, this paper uses survey data for analysis. The samples are only distributed in three provinces and 20 poverty-stricken counties, not covering all provinces in the country. The poverty alleviation microcredit involves loans and interest subsidies, both of which have an impact on the income of poor households. Limited by data, this paper only analyzes the effect of loans on the income of poor households. Besides, sample data were only collected once in 2019, which fails to reflect the long-term effect of the implementation of the poverty alleviation microcredit policy. Some variables are likely to have an endogeneity problem. The analysis results have a certain degree of deviation, which will be the direction of further research. More abundant sample panel data are needed. In-depth study on the impact of the poverty alleviation microcredit policy on the income of poor households is also needed. The research on the implementation effect of the poverty alleviation microcredit policy is helpful to the further adjustment and optimization of the financial poverty alleviation policy.

Author Contributions: Conceptualization, X.H. and J.Y.; methodology, X.H.; software, B.C.; formal analysis, J.Y.; investigation, J.Y. and B.C.; resources, J.Y. and B.C.; data curation, J.R.; writing-original draft preparation, J.Y.; writing-review and editing, J.R.; visualization, J.Y.; supervision, J.R.; project administration, J.R.; funding acquisition, J.R., X.H. and J.Y. made equal contributions to the article. All authors have read and agreed to the published version of the manuscript.

Funding: This research was funded by National Natural Science Foundation of China (grant number 71873129).

Conflicts of Interest: The authors declare that there is no conflict of interest.

\section{References}

1. IPRCC. Poverty Reduction Briefing IPRCC. Available online: https://ccprr.bnu.edu.cn/zwjpxx/gwjpxx/73287. html (accessed on 25 February 2020).

2. Wu, L.J.; Li, D. The effects of financial capital on rural households'income under the background of precise poverty alleviation-From the perspective of income stratification and regional differences. J. Agrotech. Econ. 2019, 6, 61-72.

3. Wen, T.; Zhu, J.; Wang, X.H. Elite capture of rural credit market in China: Stratified comparison between poor and non-poor counties. Econ. Res. J. 2016, 2, 111-125.

4. Ba, S.S.; Luan, X.J. Analysis and countermeasures on the availability of rural micro credit. Economist 2009, 4, 38-44.

5. Khandker, S.R. Microfinance and poverty: Evidence using panel data from Bangladesh. World Bank Econ. Rev. 2005, 19, 263-286. [CrossRef]

6. Ayuub, S. Impact of microfinance on poverty alleviation: A case study of NRSP in Bahawalpur of Pakistan. Int. J. Acad. Res. Account. Financ. Manag. Sci. 2013, 3, 119-135. 
7. Dong, X.L.; Xu, H. An empirical analysis on influence factors of rural financial exclusion: Based on the outlets distribution of financial institutions. J. Financ. Res. 2012, 9, 115-126.

8. Hu, Z.Y.; Luo, L.D. The utility research of micro credit in reduction of rural poverty based on panel model. Theory Pract. Financ. Econ. 2016, 37, 10-15.

9. Micro-Credit Administration System Research Group. A research report on improving and perfecting the government micro-credit poverty alleviation administration system. Contenporary China Hist. Stud. 2001, 5, 116-126.

10. Jia, J.X.; Qin, C.; Liu, Y.J. Policy design for the integration of "top down" and "bottom up": An empirical analysis based on poverty alleviation rural development projects. Soc. Sci. China 2017, 9, 68-89.

11. Imai, K.S.; Gaiha, R.; Thapa, G.; Annim, S.K. Microfinance and poverty-A macro perspective. World Dev. 2012, 40, 1675-1689. [CrossRef]

12. Yin, Z.C.; Guo, P.Y.; Zhang, L.W. "Active spring from the source": The impact of targeted poverty alleviation policy on household credit in rural China. Manag. World 2020, 36, 59-71.

13. Augsburg, B.; De Haas, R.; Harmgart, H.; Meghir, C. The impacts of microcredit: Evidence from Bosnia and Herzegovina. Am. Econ. J. Appl. Econ. 2015, 7, 183-203. [CrossRef]

14. Wu, L.J.; Xu, Z.Y. Empirical research of poverty alleviation effect of agriculture loans_PSM analysis based on survey data of 4976 households in western regions. J. Northwest. Agric. For. Univ. Soc. Sci. Ed. 2016, 16, 94-104.

15. Liu, X.C.; Huang, Z.H.; Cheng, E.J. Moving up the goal of microfinance: Phenomenon description and theoretical explanation. Chin. Rural Econ. 2007, 8, 23-34.

16. Lin, W.L.; Yang, C.C. Can poor farmers make effective use of poverty-stricken micro credit services? A case study on the pilot project of mutual aid funds for poor villages in Yilong County, Sichuan Province. Chin. Rural Econ. 2012, 2, 35-45.

17. Wang, X.H.; Wen, T.; Wang, D.X. County rural financial repression and income inequality among farmers. Econ. Sci. 2014, 2, 44-54.

18. Nurkse, R. Problems of Capital Formation in Underdeveloped Countries and Patterns of Trade and Development; Oxford University Press: New York, NY, USA, 1953.

19. Newman, A.F. Occupational choice and the process of development. J. Political Econ. 1993, 101, 274-298.

20. Oded, G.; Joseph, Z. Income distribution and macroeconomics. Rev. Econ. Stud. 1993, 1, 35-52.

21. Sehrawat, M.; Giri, A.K.; Mohapatra, G. The impact of financial development, economic growth and energy consumption on environmental degradation. Manag. Environ. Qual. Int. J. 2015, 5, 666-682. [CrossRef]

22. Aghion, P.; Howitt, P. Economics of Growth; MIT Press: Cambridge, MA, USA, 2009.

23. Aghion, P.; Bolton, P. A theory of trickle-down growth and development. Rev. Econ. Stud. 1997, 64, $151-172$. [CrossRef]

24. Niu, R.; Luo, J.C.; Zhang, H. Research on the farmers' credit constraints under rural property mortgage. Issues Agric. Econ. 2016, 37, 76-83.

25. Li, Y.X. Can Microcredit improve the well-being of poor people? Evidence from literature on micro-level impact evaluation. Issues Agric. Econ. 2015, 36, 86-95.

26. Yu, L.H.; Lan, Q.G.; Wu, X.Y. Analysis on farmers' satisfaction for rural land management right mortgage: Based on a survey of a province. China Land Sci. 2016, 30, 79-87.

27. Liang, H.; Luo, J.C.; Zhang, H. Borrowing behavior of rural land and its influence on farmers' income-The empirical research based on PSM Model. J. Agrotech. Econ. 2017, 10, 108-120.

28. Armendáriz, B.; Morduch, J. The Economics of Microfinance, 2nd ed.; MIT Press: Cambridge, MA, USA, 2010.

29. Besley, T. Nonmarket institutions for credit and risk sharing in low-income countries. J. Econ. Perspect. 1995, 9, 115-127. [CrossRef]

30. Eswaran, M.; Kotwal, A. Credit as insurance in agrarian economies. J. Dev. Econ. 1989, 1, 37-53.

31. Pitt, M.M.; Khandker, S.R. The impact of group-based credit programs on poor households in Bangladesh: Does the gender of participants matter? J. Political Econ. 1998, 5, 958-996. [CrossRef]

32. Zhao, W.Z.; Guo, X.M. Comparison among anti-poverty alternative models. China Rural Surv. 2000, 6, 66-72.

33. Wu, B.J.; Ge, Y.H.; Ma, J.J. Performance comparison between fiscal poverty alleviation and financial poverty alleviationin the period of targeted poverty alleviation:from the perspective of heterogeneity of poverty alleviation and multidimensional poverty. Chin. Rural Econ. 2019, 7, 21-36. 
34. Yan, J.; Qiang, G.L.; Liu, Q.J. Poverty-alleviating microcredit, farmer income, and anti-poverty performance. Financ. Econ. Res. 2019, 4, 32-44.

35. Attanasio, O.; Augsburg, B.; Haas, R.D.; Fitzsimons, E.; Harmgart, H. The impacts of microfinance: Evidence from joint-liability lending in mongolia. Am. Econ. J. Appl. Econ. 2015, 7, 90-122. [CrossRef]

36. Yunus, M. Micro-Lending and the Battle Against World Poverty; Public Affairs Books: New York, NY, USA, 2003.

37. Banerjee, A.; Duflo, E.; Glennerster, R.; Kinnan, C. The miracle of microfinance? Evidence from a randomized evaluation. Am. Econ. J. Appl. Econ. 2015, 7, 22-53. [CrossRef]

38. Wang, W.C.; Zhou, J.Y. An Empirical analysis of the income-increasing effects of credit among rural resident groups with different income levels. Chin. Rural Econ. 2012, 5, 79-86.

39. Zhu, X.; Li, Z.N. The economic impact of farm credit: An empirical investigation based on IVQR model. Syst. Eng. Theory Pract. 2007, 27, 68-75. [CrossRef]

40. Hansen, C. Instrumental quantile regression inference for structural and treatment effect models. J. Econom. 2006, 132, 491-525.

41. Li, R.; Li, N.H. Studies on the borrowing behavior of rural households and welfare effects. Econ. Res. J. 2004, 12, 96-104.

42. Li, Q.H.; Li, R.; Wang, S.G. The credit rationing of chinese rural households and its welfare loss. J. Quant. Tech. Econ. 2012, 8, 36-49.

43. Binswanger, H.P.; Khandker, S.R. The impact of formal finance on the rural economy of India. J. Dev. Stud. 1995, 32, 234-262. [CrossRef]

44. Feng, H.H. Microfinance, Self-employment of farmer and income growth-An empirical analysis based on the mediation effect. J. Audit Econ. 2016, 5, 111-119.

45. Khandker, S.; Faruqee, R.R. The impact of farm credit in Pakistan. Agric. Econ. 2003, 28, 197-213. [CrossRef]

46. Rosenbaum, P.R.; Rubin, D.B. Constructing a control group using multivariate matched sampling methods that incorporate the propensity score. Am. Stat. 1985, 39, 33-38.

47. Caliendo, M.; Kopeinig, S. Some practical guidance for the implementation of propensity score matching. J. Econ. Surv. 2008, 22, 31-72. [CrossRef]

48. Xie, Y.M.; Gao, J. An empirical study of the effects by interlinking between the rural credit and index insurance on the fluctuation of farmers' income. J. Sun Yatsen Univ. Soc. Sci. Ed. 2014, 54, 158-164.

49. Carter, M.R.; Galarza, F.B.; Boucher, S.R. Underwriting area-based yield insurance to crowd-in credit supply and demand. Sav. Dev. 2007, 31, 335-362.

50. Hill, R.V.; Viceisza, A. A field experiment on the impact of weather shocks and insurance on risky investment. Exp. Econ. 2012, 15, 341-371. [CrossRef]

51. Stein, H. World Bank agricultural policies, poverty and income inequality in sub-Saharan Africa. Camb. J. Reg. Econ. Soc. 2011, 4, 79-90. [CrossRef]

52. Jalilian, H.; Kirkpatrick, C. Does financial development contribute to poverty reduction? J. Dev. Stud. 2005, 41, 636-656. [CrossRef]

53. Claessens, S.; Feijen, E.; Laeven, L. Political connections and preferential access to finance: The role of campaign contributions. J. Financ. Econ. 2008, 88, 554-580. [CrossRef]

54. Rosenberg, R. Does microcredit really help poor people? Focus Note 2010, 1, 1-8.

55. You, J. The role of microcredit in older children's nutrition: Quasi-experimental evidence from rural China. Food Policy 2013, 43, 167-179. [CrossRef]

56. Geda, A.; Shimeles, A.; Zerfu, D. Finance and Poverty in Ethiopia: A Household-Level Analysis; UNU-WIDER: Helsinki, Finland, 2006.

57. Collins, D.; Morduch, J.; Rutherford, S.; Ruthven, O. Portfolios of the Poor: How the World's Poor Live on $\$ 2$ a Day; Princeton University Press: Princeton, NJ, USA, 2009.

58. Karlan, D.; Zinman, J. Expanding credit access: Using randomized supply decisions to estimate the impacts. Rev. Financ. Stud. 2010, 23, 433-464. [CrossRef]

59. Ding, Z.G.; Tan, L.L.; Zhao, J. The effect of rural financial development on poverty reduction. Issues Agric. Econ. 2011, 11, 72-77.

60. Akhter, S.; Liu, Y.; Daly, K. Cross country evidence on the linkages between financial development and poverty. Int. J. Bus. Manag. 2010, 5, 207-214. [CrossRef]

61. Su, J.R.; Liao, J.Z. Empirical analysis of financial development, income distribution and poverty: Based on dynamic panel. Financ. Econ. 2009, 12, 10-16. 
62. Matsuyama, K. Financial market globalization and endogenous inequality of nations. Discuss. Pap. 2001, 72, 853-884.

63. Du, F.L.; Sun, J.F. Economic growth, income distribution and poverty reduction effects: Evidence from 1991-2004. Econ. Sci. 2009, 3, 17-28. 